\title{
Effectiveness of Progressive Muscle Relaxation and Meditation Relaxation Treatment of Reduction of Blood Pressure in Hypertension Patients in the Village of Sindangagung Kuningan District
}

\author{
$1^{\text {st }}$ Lia Mulyati \\ Departement of Medical Surgical \\ Nursing \\ STIKes Kuningan Garawangi \\ Indonesia \\ liamulyati@stikku.ac.id
}

\author{
$2^{\text {nd }}$ Yana Hendriana \\ Departement of Medical Surgical \\ Nursing \\ STIKes Kuningan Garawangi \\ Indonesia
}

\author{
$3^{\text {rd }}$ Ela Nur Padilah \\ Department Midwifery \\ Student of Nursing Programe \\ STIKes Kuningan Garawangi \\ Indonesia
}

\begin{abstract}
Hypertension is a state of increased systolic blood pressure of more than $140 \mathrm{mmHg}$ and diastolic more than equal to $90 \mathrm{mmHg}$. West Java became the second province with the highest sufferers in Indonesia. Progressive muscle relaxation therapy and meditation relaxation therapy is one way of non-pharmacological therapy to stabilize blood pressure. This study aims to determine the effectiveness of progressive muscle relaxation therapy and relaxation meditation therapy to reduce blood pressure in patients with hypertension in, Sindangagung, Kuningan Regency. This study uses a quasi-experimental research design with a pretest and posttest group with control group comparison design. The sample in this study amounted to 30 people using purposive sampling technique. The research instrument used observation sheets. Data analysis consisted of univariate analysis and bivariate analysis, using paired sample $t$ test and independent sample $t$ test. The results showed there were differences in systolic and diastolic before and after progressive muscle relaxation therapy $(0,000)$ and meditation relaxation therapy (0.002). Further analysis showed that there was no difference between systolic and diastolic after progressive muscle relaxation therapy and meditation relaxation therapy with systolic $p$ value $0.929(p>0.05)$ and diastolic $p$ value 0.071 ( $p>$ 0.05). Both progressive muscle relaxation therapy and meditation relaxation both have the same effectiveness in lowering blood pressure. This therapy can be used as an appropriate non-pharmacological therapy in reducing blood pressure in people with hypertension.
\end{abstract}

Keywords-Muscle Relaxation, Meditation, Blood Pressure, Hypertension

\section{INTRODUCTION}

Hypertension is a non-communicable disease which is nicknamed as a silent killer disease, because most people do not take the disease seriously until finally sufferers experience various complications of the disease that often leads to death. WHO (World Health Organization) estimates that non-communicable diseases cause around $60 \%$ of deaths and $40 \%$ of illness worldwide and 1 billion people worldwide suffer from hypertension, $2 / 3$ of them are in developing countries with low to moderate incomes. The prevalence of hypertension will continue to rise sharply and it is predicted that in 2025 as many as $29 \%$ of adults worldwide will be affected by hypertension. Hypertension has caused an estimated 8 million deaths each year, of which 1.5 million deaths occur in Southeast Asia where 1/3 of the population suffers from hypertension ${ }^{[1]}$ Based on data from the Republic of Indonesia Ministry of Health Riskesdas (2018), the prevalence of non-communicable diseases, especially hypertension, increased $8.3 \%$ compared to 2013, from $25.8 \%$ to $34.1 \%$. West Java Province is ranked 2nd with the highest prevalence of hypertension in Indonesia ${ }^{[2]}$. In 2016 in West Java found 790,382 cases of hypertension. In Kuningan District the prevalence of hypertension in 2017 was 58,550 people with hypertension. While in Sindangagung sub-district in January-March 2019 the prevalence of hypertension was 476 people $^{[3]}$.

The rapid occurrence of hypertension is in line with changes in modern lifestyles in addition to changes in diet, activity is also a high level of stress due to increased demands in meeting the needs of $\operatorname{life}^{[4]}$. Stress has a significant contribution in increasing the incidence of patients with hypertension. In a study found a relationship between life pressure with changes in blood pressure ${ }^{[4]}$. An increase in chronic high blood pressure can trigger a variety of abnormal physiological functions such as hardening of the arteries/ atherosclerotics, impaired kidney function, heart failure, and liver, to prevent the occurrence of these complications the patient's ability to control blood pressure in the normal range is needed ${ }^{[4]}$.

Most of the efforts made by hypertension sufferers are using pharmacological therapy, but in carrying out this therapy often found obstacles that affect the effectiveness of 
therapy including negligent patients against pharmacological treatment, or unable to tolerate the side effects of therapy and lack of patient compliance with therapy, the condition causes the growth of complementary therapies in the management of chronic diseases such as music therapy, progressive muscle relaxation therapy, meditation, yoga etc.

Many studies have explained the effect of progressive muscle relaxation on blood pressure, as well as with meditation. The results of a study conducted by Tyani et al (2015) found that there was a significant difference between the average blood pressure before and after progressive muscle relaxation was given with a $\mathrm{p}$ value of 0.001 (systolic) and a $\mathrm{p}$ value of 0,000 (diastolic) $(\mathrm{p}<0,05)$ in patients with hypertension ${ }^{[5]}$. Equivalent to the research of Martin \& Mardian (2016), the results were obtained that prior to meditative therapy, systolic blood pressure in the elderly was $148.25 \mathrm{mmHg}$ and the diastolic blood pressure was $92.25 \mathrm{mmHg}$ and after being given a meditation therapy, the blood pressure in the elderly decreased. systolic mean $140.75 \mathrm{mmHg}$ and mean diastolic blood pressure $86.75 \mathrm{mmHg}^{[6]}$. It can be concluded that there is an effect of meditation therapy on changes in blood pressure in the elderly who have hypertension with a $p$ value of 0,000 (p $<0.05)^{[6]}$. Research conducted by Astuti and Rekawati 2017 shows that complementary therapy of muscle relaxation and music therapy can reduce blood pressure by $29.2 \mathrm{mmHg}$ (systolic) and $16.2 \mathrm{mmHg}$ (diastolic), while research conducted by Baharudin et al (2013), shows that captopril can reduce systolic blood pressure and diastolic blood pressure by $29.16 / 11.83 \mathrm{mmHg}$ and amlodipine can reduce systolic blood pressure and diastolic blood pressure by 2.94 / $16.38 \mathrm{mmHg}^{[7]}$. The research proves that complementary therapy is quite effective in reducing blood pressure in people with hypertension.

The purpose of this study was to determine the effectiveness of progressive muscle relaxation therapy and relaxation meditation therapy to reduce blood pressure in patients with hypertension in Kertaungaran Village, Sindangagung Subdistrict, Kuningan Regency in 2019

\section{RESEARCH METHODS}

The type of research used is quasi experiment. By using a pretest and posttest group with control group comparison design. The sample in this study were 30 people with a division of 15 people in the intervention group I progressive muscle relaxation therapy and 15 people in the intervention group 2 in meditation relaxation therapy. Samples were taken purposively with the inclusion criteria suffering from mild to moderate hypertension, aged 45 - 59 years and exclusion; do not have muscle injury, do not suffer from diseases that cause hypertension or complications from hypertension like. The intervention was carried out for 20 minutes, carried out 2 times a week for 2 weeks. The instruments used were mercury sphygmomanometer, stethoscope, chair, pillow / mat and observation sheet. Univariate analysis used is the central tendency and for bivariate analysis the paired sample $t$ test and independent sample $\mathrm{t}$ test were used.

\section{RESEARCH RESULTS}

The results of studies of changes in systolic and diastolic pressure on PMR interventions and relaxation meditation are shown in table I.

TABLE I. INTERVENTION OF PROGRESSIVE MUSCLE RELAXATION AND MEDITATION ON REDUCING SYSTOLIC AND DIASTOLIC PRESSURE OF HYPERTENSION SUFFERERS

\begin{tabular}{|l|c|c|c|c|}
\hline \multicolumn{1}{|c|}{ Variable } & $\begin{array}{c}\text { Pre } \\
\text { Mean } \pm \text { SD }\end{array}$ & $\begin{array}{c}\text { Post } \\
\text { Mean } \pm \text { SD }\end{array}$ & $\mathrm{p}^{*}$ & $\mathrm{p}^{* *}$ \\
\hline Sistolik & $153.7 \pm 10.3$ & $144 \pm 10.7$ & 0.000 & 0.929 \\
- PMR & $153.3 \pm 9.8$ & $144.3 \pm 9.6$ & 0.000 & \\
- Meditasi & $91.0 \pm 5.4$ & $84.7 \pm 4.4$ & 0.002 & 0.071 \\
\hline Diastolic & $91.3 \pm 4.4$ & $88.0 \pm 5.3$ & 0.004 & \\
- PMR & $\mathrm{p} *$ Paired t test (p value with @ 0.05) \\
- Meditasi & $\mathrm{p} * *$ Test for unpaired t (p value with @ 0.05)
\end{tabular}

Average systolic pressure of hypertensive patients before PMR intervention $153.7 \mathrm{mmHg}$ and after intervention average systolic pressure $144 \mathrm{mmHg}$, based on the results of paired $t$ test analysis there were significant differences in average systolic pressure before and after PMR intervention with a $\mathrm{p}$ value of $0.000<0.05$. Average systolic pressure of hypertensive patients before meditation relaxation interventions $153.3 \mathrm{mmHg}$ and after intervention average systolic pressure $144.3 \mathrm{mmHg}$, based on the results of paired test analysis there were significant differences in average systolic pressure before and after PMR intervention with $\mathrm{p}$ values of $0.000<0.05$. Likewise with diastolic pressure before and after PMR intervention and relaxation meditation have significant differences with $\mathrm{p}$ values 0.002 and $0.004(<0.05)$. However, based on the results of the unpaired $t$ test it was found that there were no significant differences between PMR interventions and meditation relation to the decrease in both systolic blood pressure with a p value of 0.929 and diastolic with a $\mathrm{p}$ value of 0.071 .

\section{DISCUSSION}

PMR is a relaxation technique through two processes, namely tensing and relaxing the muscles of the body, which is a combination of breathing exercises and movements ${ }^{[8]}$. Based on the results of the study, the group undergoing progressive muscle relaxation therapy was found to have decreased systolic pressure by $9.67 \mathrm{mmHg}$, as well as diastolic pressure, which had a significant decrease of 6.33 $\mathrm{mmHg}$ and based on further analysis it was found that the $\mathrm{p}$ value was 0,000 , which means that there were differences significant systolic and diastolic pressures before and after 
progressive muscle relaxation therapy. This is in line with the results of Mahardhini \& Wahyuni (2017) research on "The Effectiveness of Progressive Muscle Relaxation and Deep Breath Relaxation in hypertensive patients in Begal Village, Kedunggalar District, Ngawi Regency" found an average decrease in systolic pressure of $22.46 \mathrm{mmHg} \mathrm{P}$ value $=0.001$, while the diastolic pressure decreased by $20.00 \mathrm{mmHg}$, with a p value of $0.000^{[9]}$.

Progressive muscle relaxation therapy is a simple and effective relaxation therapy to reduce muscle tension, reduce stress and reduce high blood pressure. This therapy is one of the simple relaxation methods that goes through two processes, namely tensing and relaxing the muscles of the body in one part of the body at a time to provide a feeling of physical relaxation. This progressive tightening and flexing of muscles is carried out in succession ${ }^{[10]}$. PMR can reduce anxiety five times per week, improve physical function, reduce sleep disorders, reduce mental disorders, and improve quality of life ${ }^{[11]}$.

According to Muttaqin (2009) states that progressive muscle relaxation can increase relaxation by decreasing sympathetic nerve activity and increasing parasympathetic nerve activity resulting in vasodilatation of arteriolar diameters $^{[5]}$. Mulyati \& Sudirman, (2017) revealed that physiologically the effects of relaxation can affect the hypothalamic-pituitary and adrenal system mechanism, this condition causes a decrease in adenocorticotropin hormone $(\mathrm{ACTH})$ in the anterior pituitary until finally a decrease in cortisol in the blood. Decreased cortisol results in a decrease in blood pressure, vasodilation of blood vessels and respiratory rate, due to decreased heart contractility and blood vessel resistance ${ }^{[12]}$. Research conducted by Yanti, et al (2016) said that during relaxation there is an extension of muscle fibers, decreased transmission of nerve impulses to the brain, decreased brain activity and other functions, which are marked by decreased pulse rate, respiratory rate and decreased blood pressure ${ }^{[13]}$.

Relaxation meditation is a method that is done by practicing the focus of the mind so that it has a clear view of the current conditions and remains calm. This practice is generally carried out by sitting quietly by regulating breathing slowly and regularly for at least 10-15 minutes. This activity, if carried out regularly, is believed to have many health benefits, including mental health13. Based on the results of the study it was known that there was a decrease in systolic pressure of 9.00 and diastolic of 3.33 with a $p$ value of 0.000 for systolic pressure and a value of 0.004 for diastolic pressure, meaning that there were significant differences in systolic and diastolic pressure before and after being given meditation therapy in patients with hypertension.

This research is also supported by research conducted by Martin \& Mardian (2016) found that hypertensive patients before and after meditation relaxation therapy has decreased systolic pressure by $7.50 \mathrm{mmHg}$ and obtained a $\mathrm{p}$ value of $0,000^{[6]}$. Yustina and Rejeki (2015) explained that when someone relaxes with deep breathing and eyes closed, the oxygen demand entering the lungs will be more adequate so that oxygen can be circulated according to the body's needs, so that it will affect the work of the heart where if the heart works optimal, the heart rate will decrease and be accompanied by a decrease in blood pressure ${ }^{[14]}$. Martin and Mardian (2016) suggested that giving relaxation meditation therapy can provide a relaxed condition, where in a relaxed condition all body systems will work well and in this condition the hypothalamus will adjust and decrease the activity of the sympathetic nervous system and increase the activity of the parasympathetic nervous system ${ }^{[6]}$.

Based on the results of the independent sample $t$ test for systolic blood pressure after progressive muscle relaxation therapy with meditation relaxation therapy, the results show that there is no difference with $p$ value $=0.929(p>0.05)$ and diastolic blood pressure after progressive muscle relaxation therapy. Meditation relaxation therapy results that there is no difference with $\mathrm{p}$ value $=0.071(\mathrm{p}>0.05)$. Relaxation is an action to provide a sense of relaxation in the body and can reduce the heart rate in the body. Relaxation is the main method used to make the body relax and relieve stress.

\section{A. Conclusion}

Progressive muscle relaxation therapy and meditation therapy are effective alternative therapies for reducing both systolic and diastolic blood pressure. Both of these therapies have the same effectiveness

B. Suggestion

Progressive muscle relaxation therapy and meditation therapy can be included in health promotion materials as an effort to control and reduce blood pressure in people with hypertension.

\section{REFERENCES}

[1] Departemen Kesehatan Republik Indonesia, "Laporan Hasil Riskesdas Indonesia," Jakarta Depkes RI, 2017.

[2] Kementrian Kesehatan Republik Indonesia, "Hasil Riskesdas," Jakarta Kementrian Kesehat. Republik Indones., 2018.

[3] Dinas Kesehatan kabupaten Kuningan, "Laporan Tahunan Penyakit Hipertensi," Kuningan Dinkes Kota Kuningan, 2017.

[4] H. Patel, R. Kathrotia, and H. Thakkar, "Effect Of Relaxation Technique On Blood Pressure In Essential Hypertension," NJIRM, vol. 3 (4), p. September-October eISSN: 0975-9840, 2012.

[5] E. S. Tyani, W. Utomo, and Y. Hasneli, "Efektifitas Relaksasi Otot Progresif Terhadap Tekanan Darah Pada Pasien Hipertensi Essensial," JOM, vol. 2 No. 2, 2016.

[6] W. Martin and P. Mardian, "Pengaruh Terapi Meditasi Terhadap Perubahan Tekanan Darah Pada Lansia Yang Mengalami Hipertensi," IPTEKS Terap., vol. $10 . \mathrm{i} 4$ (211, 2016.

[7] N. F. Astuti, E. Rekawati, and D. N. K. Wati, "Decreased blood pressure among community dwelling older adults following progressive muscle relaxation and music therapy (RESIK).," $B M C$ Nurs., vol. Vol 18 (Su, 2019.

[8] M. M. Mhaske, P. D. T, and V. K. Jatgap, "Comparison of the effectiveness of visual imagery technique and progressive relaxation technique on anxiety and depression in subjects with moderate chronic obstructive pulmonary disease," Asian $J$. Pharm. Clin. Res., vol. 11(6), pp. 318-323, 2018.

[9] A. Mahardhini and W. Wahyuni, "Efektifitas Relaksasi Otot Progresif Dan Relaksasi Napas Dalam Terhadap Tekanan Darah Penderita Hipertensi Di Desa Begal Kecamatan Kedunggalar Kabupaten Ngawi," J. 7th Univ. Res. Colloqium, p. STIKES PKU Muhammadiyah Surakarta, 2018.

[10] K. V, D. A. S, and P. R, "Effectiveness of Progressive Muscle Relaxation Technique on Stress and Blood Pressure among Elderly with Hypertension," IOSR J. Nurs. Heal. Sci., vol. 3, pp. $1-6,2014$.

[11] K. Kusnanto, M. A. Murtadho, L. Herawati, and H. Arifin, "The Comparison Of Progressive Muscle Relaxation Frequency On Anxiety, Blood Pressure, And Pulse Of Haemodialysis Patients," J. Ners, vol. 14 (1), 2019. 
[12] L. Mulyati and R. M. Sudirman, "Efektivitas Terapi Musik Degung Sunda Terhadap Penurunan Tekanan Darah Pada Penderita Hipertensi," J. Ilmu Kesehat. Bhakti Husada, vol. 6, 2017.

[13] N. Annisa and M. Maryatun, "Perbedaan Pengaruh Pemberian Meditasi Sederhana dan Latihan Deep Breathing Terhadap Penurunan Tekanan Darah Pada Penderita Hipertensi di Posyandu
Lansia Mentari Senja Semanggi Surakarta," J. 7th Univ. Res. Colloqium, p. STIKES PKU Muhammadiyah Surakarta., 2018.

[14] M. S. Nuwa, Kusnanto, and S. Utami, "Modul Kombinasi Terapi Progressive Muscle Relaxation Dengan Spiritual Guided Imagery And Music," p. Fakultas Keperawatan Universitas Airlangga, 2018. 